\title{
Genetic identification of chemotactic transducers for amino acids in Pseudomonas aeruginosa
}

\author{
Kazunori Taguchi, Hiroyuki Fukutomi, Akio Kuroda, Junichi Kato and \\ Hisao Ohtake
}

Department of

Fermentation Technology, Hiroshima University, Higashi-Hiroshima, Hiroshima 739, Japan
Author for correspondence: Hisao Ohtake. Tel: +81 824247756 . Fax: +81 824227191. e-mail: hohtake@ipc.hiroshima-u.ac.jp

Keywords: chemotaxis, amino acids, transducer, Pseudomonas aeruginosa

\section{INTRODUCTION}

Many bacteria show chemotactic responses towards Lamino acids commonly found in proteins (Boyd et al., 1983; Mesibov \& Adler, 1972; Ordal \& Gibson, 1977). Escherichia coli is strongly attracted to L-alanine, Lasparagine, L-aspartate, L-cysteine, L-glutamate, glycine and $\mathrm{L}$-serine, but is repelled by hydrophobic amino acids including L-isoleucine, L-leucine, L-phenylalanine, Ltryptophan and L-valine (Hedblom \& Adler, 1983; Mesibov \& Adler, 1972; Tso \& Adler, 1974). The E. coli chemotactic response for L-amino acid attractants is mediated by two methyl-accepting chemotaxis proteins (MCPs) which are the products of the tar and tsr genes

Abbreviations: $H C D$, highly conserved domain; MCP, methyl-accepting chemotaxis protein.

The DDBJ accession number for the sequences of pctC, orf1 and pctB reported in this paper is D86947.
(Boyd et al., 1983; Clark \& Koshland, 1979). Salmonella typhimurium, which has a sensory system very similar to that of $E$. coli, is strongly attracted to five of the Lamino acids that are also strong attractants for $E$. coli (Melton et al., 1978). All 20 commonly occurring Lamino acids serve as attractants for Bacillus subtilis (Ordal \& Gibson, 1977). In B. subtilis, the McpB protein is responsible for detecting a subset of $\mathrm{L}$-amino acids that includes $\mathrm{L}$-asparagine, $\mathrm{L}$-aspartate, $\mathrm{L}$-glutamine and L-histidine, although only chemotaxis towards L-asparagine is completely deficient in the absence of this transducer (Hanlon \& Ordal, 1994).

Pseudomonas aeruginosa is strongly attracted to 20 commonly occurring L-amino acids (Kuroda et al., 1995). A nonmetabolizable amino acid, $\alpha$-aminoisobutyric acid, also elicits a strong chemotactic response from $P$. aeruginosa (Craven \& Montie, 1985). The taxis towards L-amino acids is subjected to control by nitrogen availability in a manner similar to the control of various enzymes of nitrogen metabolism (Craven $\&$ 
(a)

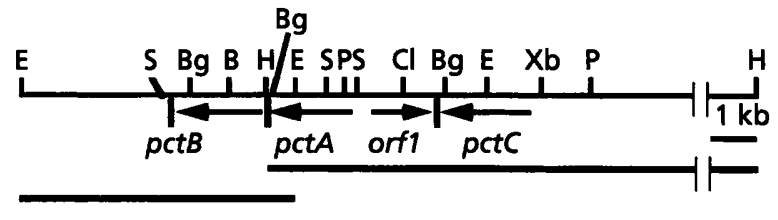

(b)

PPT08

PPT09

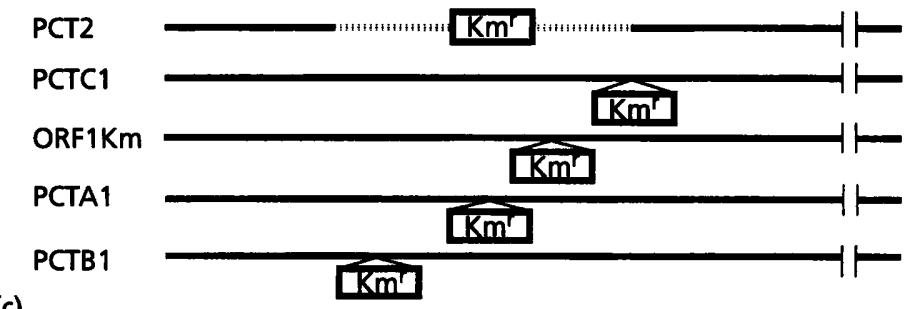

(c)

PCT10 (pctABC, orf1)

PCT08.12 (pctC)

PCT08.13 (orf1)

РСT08.14 (pctA)

РСT09.1 (pctB)
Fig. 1. (a) Restriction map of the $24 \mathrm{~kb}$ EcoRI-HindIII fragment from $P$. aeruginosa chromosomal DNA and the subcloned derivatives. Horizontal bars show the DNA fragments subcloned into vector plasmids. The location and orientation of the pctB, pctA, orf1 and pctC genes is indicated by horizontal arrows. Vertical bars below the restriction map show proposed transcriptional terminators. Restriction sites: B, BamHI; Bg, Bglll; Cl, Clal; E, EcoRl; H, HindIII; P, Pstl; S, Sall; Xb, Xbal. (b) Disruption construct map of chromosomal DNA of strains PCT2, PCTC1, ORF1Km, PCTA1 and PCTB1. The kanamycin-resistance gene is denoted by $\mathrm{Km}^{\mathrm{r}}$. (c) Plasmids used for complementation analysis. Horizontal bars show the inserts derived from the $24 \mathrm{~kb}$ EcoRI-HindIII fragment.
Montie, 1985). Recently, we cloned a chemotactic transducer gene, designated pctA (Pseudomonas chemotactic transducer $\mathrm{A}$ ), by phenotypic complementation of a $P$. aeruginosa mutant defective in taxis towards $L-$ serine but responsive to peptone (Kuroda et al., 1995). PctA is an integral membrane protein of 629 amino acids which shows high similarity to the enteric MCPs. In vivo methyl labelling experiments with $\mathrm{L}-[$ methyl$\left.{ }^{3} \mathrm{H}\right]$ methionine showed that the chromosomal pctA mutant lacked an MCP with a molecular mass of approximately $68 \mathrm{kDa}$.

MCPs from a wide variety of organisms have been shown to possess a region of high conservation within the cytoplasmic portion of the MCP, referred to as the highly conserved domain (HCD). We previously showed that PctA possesses the HCD within its C-terminal domain (Kuroda et al., 1995). Here, we report the cloning, sequencing and characterization of two other chemotactic transducer genes, designated $p c t B$ and $p c t C$, from $P$. aeruginosa. The newly identified chemotactic transducers also possessed the HCD within their Cterminal domain and were involved in chemotaxis towards $\mathrm{L}$-amino acids and some amino acid catabolites.

\section{METHODS}

Bacterial strains and plasmids. The bacterial strains and plasmids used in this study are listed in Table 1. E. coli MV1184 was used for plasmid construction and DNA manipulation. P. aeruginosa and E. coli strains were grown at $37^{\circ} \mathrm{C}$ with shaking in $2 \times$ YT medium (Sambrook et al., 1989). This medium was also used for preparation of $P$. aeruginosa cells for chemotaxis assays and electroporation. For $E$. coli, antibiotics used for selection were $50 \mu \mathrm{g}$ kanamycin $\mathrm{ml}^{-1}, 50 \mu \mathrm{g}$ ampicillin $\mathrm{ml}^{-1}$ and $20 \mu \mathrm{g}$ tetracycline $\mathrm{ml}^{-1}$. $P$. aeruginosa transformants were selected with $1 \mathrm{mg}$ kanamycin $\mathrm{ml}^{-1}, 300 \mu \mathrm{g}$ carbenicillin $\mathrm{ml}^{-1}$ or $200 \mu \mathrm{g}$ tetracycline $\mathrm{ml}^{-1}$.
Chemotaxis assay. The computer-assisted capillary assay method was carried out as described previously (Nikata $e t$ al., 1992). Cells in a $20 \mu \mathrm{l}$ suspension were placed on a coverslip, and the assay was started by placing the coverslip upside down on the U-shaped spacer to fill the chemotaxis chamber with the cell suspension. Cells were videotaped through a phasecontrast microscope (IMT-2, magnification $\times 300$, bright field; Olympus) fitted with a $20 \times$ objective (LWDCDPlan; Olympus) and a video camera (BR9000; Hitachi). Digital image processing was used to count the number of bacteria accumulating towards the mouth of a capillary containing a known concentration of an attractant plus $1 \%$ agarose. The strength of chemotactic response was determined by the number of bacteria accumulating around the mouth of capillary within $1 \mathrm{~min}$ after the start of microscopic observation. The lower limit of detection was 50 . The chemotaxis buffer used was $10 \mathrm{mM}$ HEPES buffer ( $\mathrm{pH} 7$ ). All chemicals used for chemotaxis assays were reagent grade.

DNA manipulation and sequencing. Standard procedures were used for plasmid DNA manipulation and agarose gel electrophoresis (Sambrook et al., 1989). P. aeruginosa chromosomal DNA was prepared as described previously (Kato $e t$ al., 1994). P. aeruginosa was transformed by electroporation (Kato et al., 1994). DNA sequence was determined by dideoxy chain-termination method using an Auto Cycle Kit (Pharmacia) and an ALFred DNA sequencer (Pharmacia).

Plasmid construction. To obtain a DNA fragment containing downstream sequences of the $p c t A$ gene, EcoRI fragments of 6-10 kb were recovered from PAO1 chromosomal DNA and inserted into an EcoRI site of pCP19 (Goldberg \& Ohman, 1987). Plasmid pPT09 was selected by Southern hybridization with the $3^{\prime}$ end of the $p c t A$ gene as a DNA probe.

To construct a null mutant, strain PCT2, which contains a deletion in the entire $p c t C$, orf1, $p c t A$ and $p c t B$ genes, a $1.4 \mathrm{~kb}$ $X b a I-E c o R I$ (blunt-ended) fragment of plasmid pPT08 (Kuroda et al., 1995) and a $4.4 \mathrm{~kb}$ BglII (blunt-ended)-EcoRI fragment of plasmid pPT09 were ligated with a blunt-ended $1.3 \mathrm{~kb}$ PstI fragment containing a kanamycin-resistance $\left(\mathrm{Km}^{\mathrm{r}}\right)$ 
gene cassette from pUC4K (Pharmacia). The resulting $7 \cdot 1 \mathrm{~kb}$ XbaI-EcoRI fragment was cloned into pBluescriptIIKS $(+)$. This recombinant plasmid was then transformed into strain PAO1 to construct the null mutation by the direct gene replacement technique (Kuroda et al., 1995). $\mathrm{Km}^{\mathrm{r}}$ transformants were selected on $2 \times$ YT plates supplemented with kanamycin $\left(1 \mathrm{mg} \mathrm{ml}^{-1}\right)$. The deletion-insertion mutation of strain PCT2 was confirmed by Southern blot analysis.

Plasmid pPT08.8 was constructed by inserting a $6.5 \mathrm{~kb}$ $\mathrm{X} b a \mathrm{I}-H$ indIII fragment of pPT08 into pUC119. Plasmid pPT09.3 was constructed by inserting a $7 \cdot 0 \mathrm{~kb}$ EcoRI fragment of pPT09 into an EcoRI site of plasmid pUC119. Plasmids pPT09.4 and pPT09.5 were constructed from pPT08.8 by interrupting the $p c t C$ gene at the EcoRI site and the orf1 gene at Clal site with a $\mathrm{Km}^{\mathrm{r}}$ gene from pUC4K, respectively. Plasmid pPT09.6 was made from pPT09.3 by interrupting the $p c t B$ gene at the BamHI site with a $\mathrm{Km}^{\mathrm{r}}$ gene from pUC4K. Plasmids pPT09.4, pPT09.5 and pPT09.6 were transformed into strain PAO1 to make mutations of the $p c t C$, orf1 and $p c t B$ genes, respectively. Strain PCTA1, which contained an insertional mutation of the pctA gene, has been described previously (Kuroda et al., 1995).

To generate plasmid pPT10, which contained the entire $p c t C$, orf1, $p c t A$ and $p c t B$ genes, a $2.8 \mathrm{~kb}$ HindIII-Sall fragment of pPT09 was ligated with a $6.5 \mathrm{~kb}$ HindIII-Xbal fragment of pPT08. The resulting $9.3 \mathrm{~kb}$ XbaI-SalI fragment was then cloned into pCP19. Plasmids pPT08.12, pPT08.13, pPT08.14 and pPT09.1 were constructed by cloning the $p c t C$, orf $1, p c t A$ and $p c t B$ genes into vector $\mathrm{pMMB} 66 \mathrm{EH}$, respectively. These plasmids were introduced into strain PCT2 by transformation, and the transformants were grown without IPTG in $2 \times$ YT medium containing $0.3 \mathrm{mg}$ carbenicillin $\mathrm{ml}^{-1}$ for $18 \mathrm{~h}$.

\section{RESULTS}

\section{Isolation of chemotactic transducer genes}

To determine whether the $p c t A$-flanking region contains additional genes encoding MCPs, plasmids pPT08 and pPT09 (Fig. 1a) were first digested with several restriction enzymes and subcloned into pUC119. The resulting plasmids were then analysed by Southern blot analysis using the $3^{\prime}$ end of the pctA gene as a DNA probe. The DNA probe hybridized with a $2.8 \mathrm{~kb}$ HindIII-SalI fragment of pPT09 and a $6.5 \mathrm{~kb}$ HindIII-XbaI fragment of pPT08 (data not shown). However, no positive hybridization signal was detected with a $3.9 \mathrm{~kb}$ EcoRI-SalI fragment of pPT09 and a $10 \mathrm{~kb}$ HindIII-XbaI fragment of pPT08. These results suggested that there were $P$. aeruginosa genes encoding proteins homologous to PctA in the $2.8 \mathrm{~kb}$ HindIII-SalI and $4.3 \mathrm{~kb}$ XbaI-SalI regions (Fig. 1a). These DNA fragments were subcloned for sequence analysis.

\section{DNA sequence analysis}

DNA sequence analysis revealed three open reading frames, designated $p c t C$ ( 633 codons), orf1 (496 codons) and $p c t B$ (630 codons), in the region flanking the $p c t A$ gene (Fig. 1a). These ORFs contained the codon-choice pattern characteristic of $P$. aeruginosa (Coyne $\&$ Gold-

TM1

PctA

PCtB

PetC

PctA

PCtB

PCtC

PCEA

PCEC

PCtA

PCtB

PctC

Pcta

PCtB

Patc

PCtA

PetB

PCtC

PCtA

PCtB

PctC

PetA

PetB

PctC

PctA

PctC

PCtA

PctB

PctC

PctA

PetC

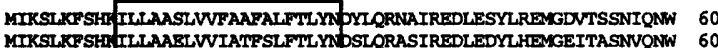

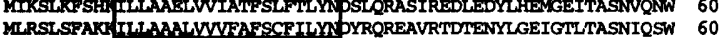
MLRSLSFAKR TLLAAALYVVFAFSCFIL W PYRQREAVRTDTENYLGEIGTLTASNIQSW

LOCRLLLVEQTAQTLARDHSPETVSAL--LEQPALTSTFSFTYIOQQD-GVFTMRPDSEM 117 LSCRILLIENLAQTLARDHSPETTQAL--LERPLLGSTFLFTYLOQTD-GTYTARPTSSDL 117 LEGRMGILEGLASQLALLDQPDEANIARQLEOPUFSRNFASVYLGEAASGTFTMRPYDAM 120

PAGYDPRSRPWYKDAVAAGELILITEPYVDAATQELIITAATPVKKAAGNILGVGGDLSLK 177

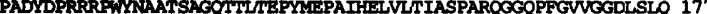
PEGYDPRTRAWYKDALAADRLIVIEPFVDAGTGEQILAMSLPVRHAGQLLGVAAGEWKLE 180

TUVI INSLDE SGYYYAFL VSGDGKILVHPDKGQVIKTLSEVYPQNTPKIATGFSEAELH 237 TVVKI INST DEGG

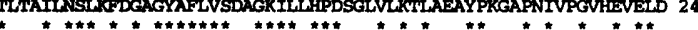

\section{TM2}

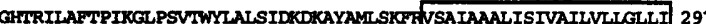
GNTRILSFSPVKGLSGLDWYIGISVDKDKAYAMLTKLFISATVAALIAVVATVLLLIGMLI 297

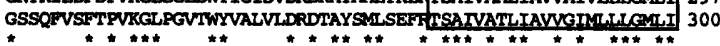

RILWQPIHIMGRAWQDIADGBCDUTYRIAVTSRDEFGVLCDAFNQFVERIHRSIREVAGT 357 RVUNPLIDDGRAYQDIAQGEGDLTKRLKVTSNDEFGALAISFNRFVERIHESIREVAGT 357 RVWOPUIDUGRAYQDIAQGECDLTKRLKVTSNDEFGTIANAFNRFVERIFESIREVAGT 360

K1

AHKTH HOVSQLVWNASNSSYAANSDEQSNE ENSVAAAINRLGAAAQEIARNA ADASHHASDA 417 ARQLFDVAQLVVASSSSSYANSDEQSNR WNSVAAAINELGAAAQEIARND ADASTHASDA 417

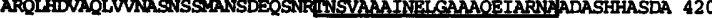

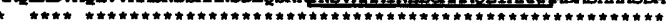

NHQAEDCKOWVEQTIRAYNEISEKKISASCANIEALNSRTVNIGQILEV FGISEOTNLIA 477 MHOAEDCKOUVEOTIRAMAEL SEKI SASCANIEALNSRTVNICOILEVIKGISEOTNTLA 477 NHOAEDGRQVVEQTIRANAIEI SEK ISASCANIEALNSRTVNIGQILEV HKGISEOTWILA 480

\section{HCD}

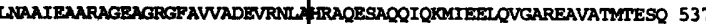
INAAIEAARAGEAGRGFAVVADEVRNLF IRAQESADQ IOKMIEELOIGAQEAVSTMTESO 537

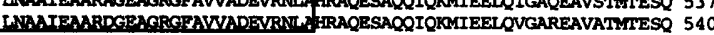

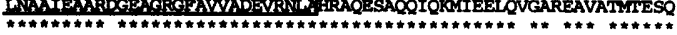

RYSLESVEIANRAGESLSSVTRRIGEID CANQSVATATEEQTAVVDSL DITEINILNQ 597 RYSLRSVEIANRAGERLSSVTGRIAEIDE YNQSVATATEEQTAVVDS NDITEINTLNQ 597 RYSLRSVEIANRAGERLGSVTSRIGEID S

EGVERIOATLRACGETETOACRLRQLVDSFKI

BGVENLOTLLACGELLTOAGRLRQLVDSFI

BOVENLOATLRACGEMLIOAAGLRRKVDSFTKI

629

629

Fig. 2. Amino acid sequence comparison of PctA,PctB and PctC. Dash marks denote gaps introduced into the sequence to improve the alignment. The alignment was generated by the $M-$ ALIGN program (DDBJ). Boxed amino acid sequences show possible transmembrane domains (TM1, TM2), methylation domains (K1, R1) and HCD. Asterisks indicate identical amino acids among three predicted proteins.

berg, 1995); a strong preference for either $G$ or $C$ was found in codon positions 3 and 1 in this order, and the second codon position was far less biased. Each gene was preceded by a Shine-Dalgarno sequence and followed by an inverted repeat, suggestive of a transcriptional terminator (Fig. 1a).

The $p c t B$ and $p c t C$ genes encode polypeptides with calculated masses of $68.1 \mathrm{kDa}$ and $68.4 \mathrm{kDa}$, respectively. Computer analysis revealed that $\mathrm{PctB}$ and $\mathrm{PctC}$ were highly similar to PctA (Fig. 2). Overall, PctB and PctC had 81 and $75 \%$ identity ( 97 and $91 \%$ similarity), 
Table 1. Bacterial strains and plasmids used in this study

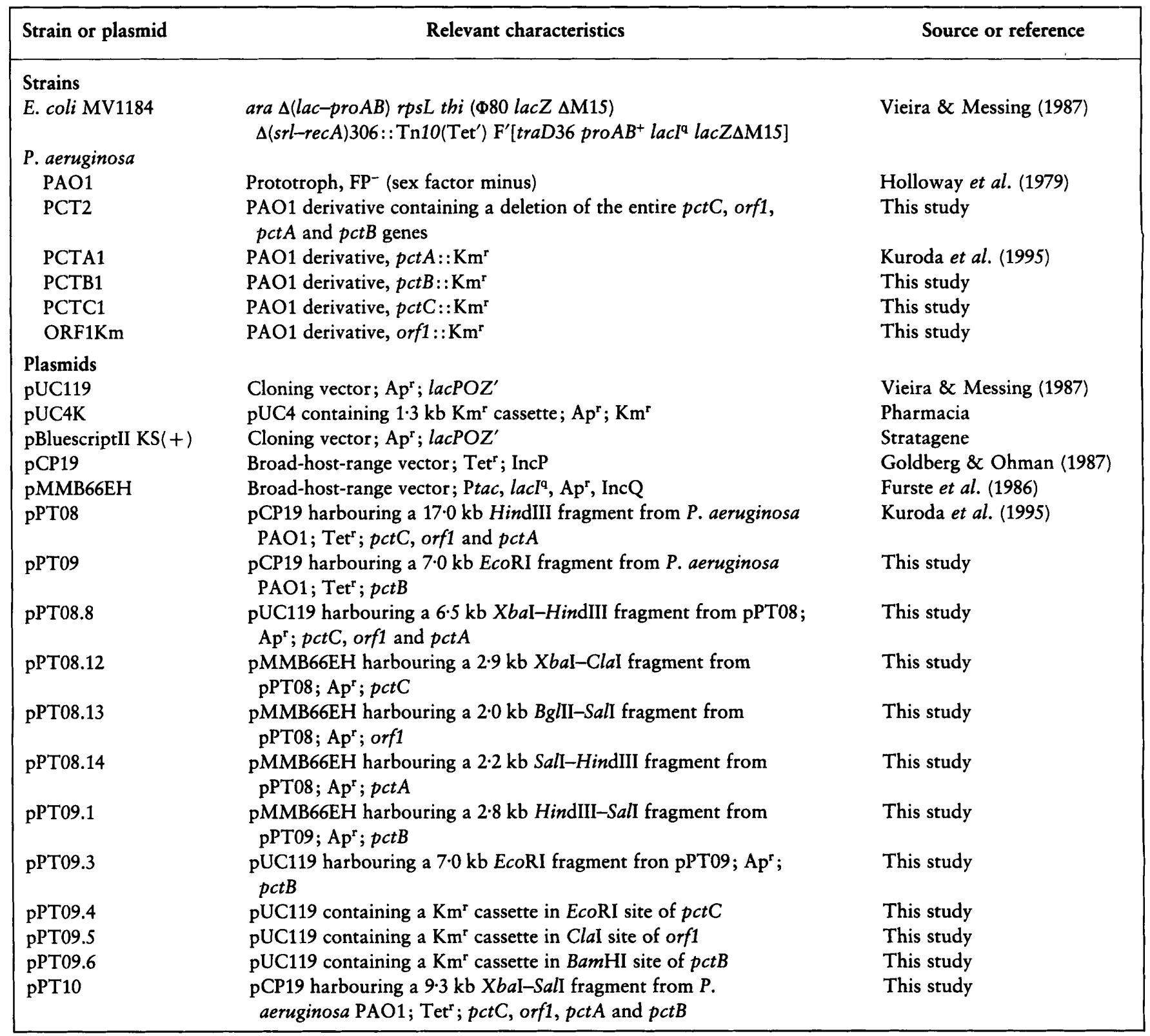

respectively, to PctA. Hydropathy plots (Kyte \& Doolittle, 1982) of PctB and PctC revealed two hydrophobic segments (TM1 and TM2) at N-terminal and central portions (data not shown). These segments are characteristic of transmembrane regions separating the cytoplasmic and periplasmic domains. The putative cytoplasmic domain of PctA, PctB and PctC was strikingly conserved $(94 \%$ amino acid identity and $98 \%$ similarity). Two potential methylation sites (K1 and R1) were also conserved among these proteins (Fig. 2).

\section{Chemotaxis assays with deletion-insertion mutants}

A series of deletion-insertion mutants was constructed by direct gene replacement. Computer-assisted capillary assays were performed with these mutant strains to quantitate chemotaxis towards 20 commonly occurring L-amino acids (Table 2). Strain PCT2, which contains a deletion of the entire $p c t C$, orf $1, p c t A$ and $p c t B$ genes (Fig. 1b), was defective in taxis towards all L-amino acids. Plasmid pPT10, which harbours the entire pctC, orf1, $p c t A$ and $p c t B$ genes (Fig. 1c), restored the ability of strain PCT2 to respond to all L-amino acids, indicating that the mutation phenotype of strain PCT2 was not due to a polar effect (Table 2). The pct $A$ mutant PCTA1 was impaired in taxis to 17 amino acids. The pct $B$ mutant PCTB1 failed to respond to L-glutamine, while no chemotactic defect was detected with the $p c t C$ mutant PCTC1. The orf1 mutant ORF1Km also showed no defect in chemotaxis towards $20 \mathrm{~L}$-amino acids. 
Table 2. Chemotactic response of $P$. aeruginosa strains towards 20 commonly occurring L-amino acids at $10 \mathrm{mM}$

The strength of chemotactic response was determined by the number of bacteria accumulating around the mouth of a capillary within $1 \mathrm{~min}$ after the start of microscopic observation (Nikata et al., 1992). ++ , More than 150 cells per videotape frame; + , less than 150 cells per videotape frame; - , no detectable response.

\begin{tabular}{|c|c|c|c|c|c|c|c|c|c|c|c|}
\hline Amino acid & PAO1 & PCT2 & $\begin{array}{c}\text { PCT2 (pPT10) } \\
\text { pctABC, orf1 }\end{array}$ & $\begin{array}{c}\text { PCT2 } \\
\text { (pPT08.14) } \\
\text { pctA }\end{array}$ & $\begin{array}{c}\text { PCT2 } \\
\text { (pPT09.1) } \\
\text { pctB }\end{array}$ & $\begin{array}{c}\text { PCT2 } \\
\text { (pPT08.12) } \\
\text { pctC }\end{array}$ & $\begin{array}{c}\text { PCT2 } \\
\text { (pPT08.13) } \\
\text { orf1 }\end{array}$ & PCTA1 & PCTB1 & PCTC1 & ORF1Km \\
\hline L-Alanine & ++ & - & ++ & ++ & + & - & - & + & ++ & ++ & ++ \\
\hline L-Arginine & ++ & - & ++ & ++ & ++ & - & - & + & ++ & ++ & ++ \\
\hline L-Asparagine & ++ & - & ++ & ++ & - & - & - & - & ++ & ++ & ++ \\
\hline L-Aspartate & + & - & + & - & - & - & - & + & + & + & + \\
\hline L-Cysteine & ++ & - & ++ & $+t$ & - & - & - & - & ++ & ++ & ++ \\
\hline L-Glutamine & ++ & - & ++ & - & ++ & - & - & ++ & - & ++ & ++ \\
\hline L-Glutamate & + & - & + & + & + & - & - & + & + & + & + \\
\hline Glycine & + & - & + & + & - & - & - & - & + & + & + \\
\hline L-Histidine & ++ & - & ++ & ++ & - & ++ & - & + & ++ & ++ & ++ \\
\hline L-Isoleucine & ++ & - & ++ & ++ & - & - & - & - & ++ & ++ & ++ \\
\hline L-Leucine & ++ & - & ++ & ++ & - & - & - & - & ++ & ++ & ++ \\
\hline L-Lysine & ++ & - & ++ & ++ & + & - & - & + & ++ & ++ & ++ \\
\hline L-Methionine & $+t$ & - & ++ & ++ & + & - & - & + & ++ & ++ & ++ \\
\hline L-Phenylalanine & ++ & - & ++ & $+t$ & - & - & - & - & ++ & ++ & ++ \\
\hline L-Proline & ++ & - & ++ & ++ & - & ++ & - & + & ++ & ++ & ++ \\
\hline L-Serine & ++ & - & ++ & ++ & - & - & - & - & ++ & ++ & ++ \\
\hline L-Threonine & $+t$ & - & ++ & ++ & - & - & - & - & ++ & ++ & ++ \\
\hline L-Tryptophan & ++ & - & ++ & ++ & - & - & - & - & ++ & ++ & ++ \\
\hline L-Tyrosine & ++ & - & ++ & ++ & + & - & - & + & ++ & ++ & ++ \\
\hline L-Valine & ++ & - & ++ & ++ & - & - & - & - & ++ & ++ & ++ \\
\hline
\end{tabular}

To further examine the role of each gene product in Lamino acid chemotaxis, recombinant plasmids were constructed by cloning each of the four genes into plasmid pMMB66EH (Table 1) and used to transform strain PCT2 by electroporation. Plasmid pPT08.14, which carried the $p c t A$ gene, restored the ability of strain PCT2 to respond towards all L-amino acids except L-glutamine and L-aspartate (Table 2). Strain PCT2 bearing plasmid pPT09.1, which contains the $p c t B$ gene, responded well towards $\mathrm{L}$-arginine and $\mathrm{L}$ glutamine and responded weakly towards L-alanine, Lglutamate, L-lysine, L-methionine and L-tyrosine. Introducing plasmid pPT08.12, which contains the entire $p c t C$ gene, resulted in restoration of PCT2 chemotaxis towards L-histidine and L-proline. Plasmid pPT08.13, bearing the orf1 gene, did not alter the ability of strain PCT2 to respond to L-amino acids.

To determine whether products of $\mathrm{L}$-amino acid catabolism are also sensed by the PctABC system, amino acids catabolites, including urocanate, pyruvate, 2oxoglutarate, agmatine, cadaverine, putrescine and 4aminobutyrate, were tested for their ability to attract $P$. aeruginosa cells. Urocanate and pyruvate, which are products of L-histidine and L-alanine catabolism, respectively, were not attractive to strain PAO1 grown in $2 \times$ YT medium (data not shown). Cadaverine, which is a product of $\mathrm{L}$-lysine catabolism, was attractive to strain PAO1. Strain PAO1 was attracted to 4-aminobutyrate but not to 2-oxoglutarate, though both compounds are products of L-glutamate catabolism. $P$. aeruginosa is able to utilize agmatine as a carbon and nitrogen source (Tricot et al., 1990) but is not attracted to this compound. Interestingly, putrescine, which is a product of agmatine catabolism, was attractive to strain PAO1.
PCT2 failed to respond towards cadaverine, 4-aminobutyrate or putrescine, indicating that the PctABC system is involved in chemotaxis towards these amino acid catabolites.

\section{DISCUSSION}

In the present study, together with our previous work (Kuroda et al., 1995), we cloned and characterized a $P$. aeruginosa gene cluster encoding chemotactic transducers for L-amino acids, designated PctA, PctB and PctC. The predicted products of the $p c t A, p c t B$ and $p c t C$ genes have the typical structural features of chemotactic transducers (Boyd et al., 1983), which are as follows: a positively charged $\mathrm{N}$-terminus followed by a hydrophobic membrane-spanning region, a hydrophilic periplasmic domain, a second hydrophobic membranespanning region, and a hydrophilic cytoplasmic domain (Fig. 2). Previously, we showed that PctA is a major MCP of $P$. aeruginosa, based upon the loss of methylated bands visualized on SDS-polyacrylamide gels in the $p c t A$ null mutant (Kuroda et al., 1995). Two potential methylation sites (K1 and R1), which were identified in the cytoplasmic domain of PctA, are well conserved in both PctB and PctC. On comparing the periplasmic domains, the similarity between PctA and PctB was higher $(70 \%$ amino acid identity) than that between PctA and PctC (53\% amino acid identity). In addition, PctC is larger by three amino acids than PctA and PctB. We also performed a Southern blot analysis of PCT2 genomic DNA with the 3' end of the pctA gene (data not shown). However, no significant band was detected in PCT2 genomic DNA, suggesting that $P$. aeruginosa contains no additional $p c t A$-like genes. 


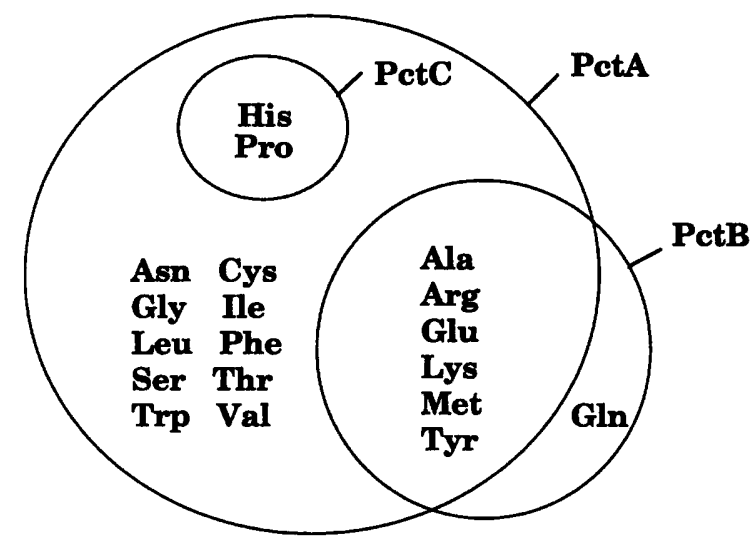

Fig. 3. Representation of 20 commonly occurring L-amino acids detected by $P$. aeruginosa chemotactic transducers. All chemotaxis assays were performed at a concentration of $10 \mathrm{mM}$.

PctA, PctB and PctC have individual specificities for Lamino acid attractants despite their relatively high similarity in the periplasmic domain. Chemotaxis assays revealed that PctA is likely a major receptor for L-amino acids in $P$. aeruginosa. This transducer detects 18 of 20 commonly occurring L-amino acids. PctB and PctC respond to seven and two L-amino acids, respectively (Table 2). Redundancies in the chemotaxis transducers were observed in $P$. aeruginosa (Fig. 3 ). In the chemotaxis assays, all L-amino acids were tested at a concentration of $10 \mathrm{mM}$, since a peak response towards Lserine was previously observed at $1-10 \mathrm{mM}$ (Nikata et al., 1992). Therefore, it cannot be ruled out that the observed specificities of PctA, PctB and PctC may reflect their different peak concentrations for $\mathrm{L}$-amino acids. It is also possible that PctA may be a relatively abundant protein among $P$. aeruginosa transducers for L-amino acids. In E. coli, Tsr and Tar are relatively abundant, at approximately 1600 and 900 copies per cell, respectively. Trg and Tap are significantly less abundant, at approximately 150 copies per cell. Plasmid pPT08.12, which contained the $p c t C$ gene, complemented the chemotaxis of strain PCT2 towards L-histidine and L-proline. However, the chromosomal $p c t C$ mutation did not affect the chemotaxis of strain PAO1 in the presence of the $p c t A$ gene. These results suggest that PctC may be less abundant compared to PctA. Based upon DNA sequence analysis, it appears that all of the pct genes are monocistronic.

Taxis towards L-aspartate was not restored in strain PCT2 harbouring each pct gene. However, strain PCT2 harbouring the entire $p c t C$, orf $1, p c t A$ and $p c t B$ genes was attracted to L-aspartate as strongly as PAO1 was. Since the L-aspartate chemotactic transducer is known to form a dimer (Milburn et al., 1991), a combination of Pct proteins might play an important role in detecting Laspartate. However, we do not have any data indicating that Pct proteins form a heterodimer.

\section{ACKNOWLEDGEMENTS}

This work was supported in part by a research grant from the Ministry of Education, Science and Culture of Japan.

\section{REFERENCES}

Boyd, A., Kendall, K. \& Simon, M. (1983). Structure of the serine chemoreceptor in Escherichia coli. Nature 301, 623-626.

Clark, S. \& Koshland, D. E., Jr (1979). Membrane receptors for aspartate and serine in bacterial chemotaxis. J Biol Chem 259, 9695-9702.

Coyne, M. J., Jr \& Goldberg J. B. (1995). Cloning and characterization of the gene $(r f c)$ encoding $\mathrm{O}$-antigen polymerase of Pseudomonas aeruginosa PAO1. Gene 167, 81-86.

Craven, R. \& Montie, T. C. (1985). Regulation of Pseudomonas aeruginosa chemotaxis by the nitrogen source. J Bacteriol 164 , 544-549.

Furste, J. P., Pansegrau, W., Frank, R., Blocker, H., Scholz, P., Bagdasarian, M. \& Lanka, E. (1986). Molecular cloning of the plasmid RP4 primase region in a multi-host range tacP expression vector. Gene 48, 119-131.

Goldberg, J. B. \& Ohman, D. E. (1987). Construction and characterization of Pseudomonas aeruginosa algB mutants: role of algB in high-level production of alginate. J Bacteriol 169, 1593-1602.

Hanlon, D. W. \& Ordal, G. W. (1994). Cloning and characterization of genes encoding methyl-accepting chemotaxis proteins in Bacillus subtilis. J Biol Chem 269, 14038-14046.

Hedblom, M. L. \& Adler, J. (1983). Chemotactic response of Escherichia coli to chemically synthesized amino acids. J Bacteriol 155, 1463-1466.

Holloway, B. W., Krishnapillai, V. \& Morgan, A. F. (1979). Chromosomal genetics of Pseudomonas. Microbiol Rev 43, 73-102.

Kato, J., Sakai, Y., Nikata, T. \& Ohtake, H. (1994). Cloning and characterization of a Pseudomonas aeruginosa gene involved in the negative regulation of phosphate taxis. $J$ Bacteriol 173, 4941-4951.

Kuroda, A., Kumano, T., Taguchi, K., Nikata, T., Kato, J. \& Ohtake, H. (1995). Molecular cloning and characterization of a chemotaxis transducer gene in Pseudomonas aeruginosa. J Bacteriol 177, 7019-7025.

Kyte, J. \& Doolittle, R. F. (1982). A simple method for displaying the hydropathic character of a protein. J Mol Biol 157, 105-132.

Melton, T., Hartman, P. E., Stratis, J. P., Lee, T. L. \& Davis, A. T. (1978). Chemotaxis of Salmonella typhimurium to amino acids and some sugars. J Bacteriol 133, 708-716.

Mesibov, R. \& Adler, J. (1972). Chemotaxis toward amino acids in Escherichia coli. J Bacteriol 112, 315-326.

Milburn, M. V., Prive, G. G., Milligan, D. L., Scott, W. G., Yeh, J., Jancarik, J., Koshland, D. E., Jr \& Kim, S.-H. (1991). Threedimensional structures of the ligand-binding domain of the bacterial aspartate receptor with and without a ligand. Science 254, 1342-1347.

Nikata, T., Sumida, K., Kato, J. \& Ohtake, H. (1992). Rapid method for analyzing bacterial behavioral responses to chemical stimuli. Appl Environ Microbiol 58, 2250-2254.

Ordal, G. W. \& Gibson, K. J. (1977). Chemotaxis toward amino acids by Bacillus subtilis. $J$ Bacteriol 129, 151-155.

Sambrook, J., Fritsch, E. F. \& Maniatis, T. (1989). Molecular Cloning : a Laboratory Manual, 2nd edn. Cold Spring Harbor, NY: Cold Spring Harbor Laboratory. 
Tricot, C., Pierard, A. \& Stalon, V. (1990). Comparative studies on the degradation of guanidino and ureido compounds by Pseudomonas. J Gen Microbiol 136, 2307-2317.

Tso, W.-W. \& Adler, J. (1974). Negative chemotaxis in Escherichia coli. J Bacteriol 118, 560-576.
Vieira, J. \& Messing, J. (1987). Production of single-stranded plasmid DNA. Methods Enzymol 153, 3-11.

Received 27 March 1997; revised 23 June 1997; accepted 4 July 1997. 